\title{
AC 2007-1092: STUDENT DESIGN OF LEHIGH UNIVERSITY GOLF FACILITIES
}

\section{Kristopher Lengieza, Weitz Golf International}

Kristopher M. Lengieza is a Project Engineer at Weitz Golf International. He earned a BS from Lehigh University. He is currently involved in constructing several buildings at Bella Collina, a Ginn Development in Montverde, FL. Kristopher has used his involvement in the 2003 Golf Practice Facility project to springboard his career into the Golf and Resort Construction Industry. Weitz Golf International is considered to be one of the top Golf Course and Hospitality Contracting companies in the world. He is also a member of the American Society of Civil Engineers and the Construction Institute.

\section{Jennifer Caffrey, Pennoni Associates Inc.}

Jennifer M. Caffrey is a Staff Engineer currently working on commercial, institutional, and municipal land development projects for Pennoni Associates Inc. in Philadelphia, Pennsylvania. She earned a B.S. in Civil Engineering in 2002 from Lehigh University and is presently working on an M.S. in Engineering Management from Drexel University. During the summer of 2000, Ms. Caffrey participated in the initial golf facility design through the Lehigh Earth Observatory (LEO) summer internship program. In the fall of that year, she utilized the Integrated Learning Experience (ILE) program to continue gaining experience in planning and design through her work on the facility.

\section{Gerard Lennon, Lehigh University}

Gerard P. Lennon is Professor of Civil and Environmental Engineering and Associate Dean of the College of Engineering and Applied Science. He earned a BS from Drexel University, and an MS and a $\mathrm{PhD}$ from Cornell University. He authored over 70 papers, and his groundwater research has been funded by five different federal and state agencies, including an NSF investigation of ocean-bottom geothermal vents in the Alvin Submarine. As a member of the American Society of Civil Engineers he organized an International Groundwater Symposium and was an associate editor of the Hydraulics Journal. He has supervised civil engineering students in interdisciplinary design projects of Lehigh sports facilities every year since 1998.

\section{John Ochs, Lehigh University}

Professor Ochs joined the Lehigh faculty in 1979 as an assistant professor of Mechanical Engineering, was promoted to associate professor in 1983, and to full professor in 1990. He founded and directed of the Computer-Aided Design Labs in the Mechanical Engineering and Mechanics Department from 1980 to 2001. From 1996 to the present, he has directed the University's Integrated Product Development (IPD) program. This multi-level program brings together students from all three undergraduate colleges to work in multidisciplinary teams on industry sponsored product development projects. In 2006 Professor Ochs received the Olympus Innovation Award for his work in technical entrepreneurship through the IPD program. Professor Ochs is a member of the American Society of Engineering Educators and past chairman of its Entrepreneurship Division, American Society of Mechanical Engineers and the Acoustical Society of America.

\section{Joe Sterrett, Lehigh University}

Joe Sterrett is the Murray H. Goodman Dean of Athletics, currently serving in his 18th year as the director for intercollegiate, club, intramural and recreational sports programs. He earned a bachelors degree in Finance and Social Psychology and a Masters degree in educational administration from Lehigh and a doctor of education degree from Temple. He has also served at Lehigh as an assistant football coach, director of undergraduate student recruitment, and assistant vice president for enrollment management. For ten years he has team-taught with Professor Vince Munley a course on the economics of the sports industry and has helped guide ten student teams 
and two summer internship teams involved in cross disciplinary sports facility design projects.

\section{Vincent Munley, Lehigh University}

Vincent Munley is Iacocca Professor of Business and Economics at Lehigh. He also serves as the university's Ombudsperson. His research is directed at the empirical study of public policy issues, in particular topics related to fiscal federalism. He earned a B.A. in economics and a B.S. in electrical engineering from Lehigh University, and Ph.D. in economics from the State University of New York, Binghamton. He spent a semester as a Fulbright Scholar at the National University of Ireland, Galway. For ten years he has team-taught with Dean of Athletics Joe Sterrett a course on the economics of the sports industry and has helped guide ten student teams and two summer internship teams involved in cross disciplinary sports facility design projects. 


\title{
Student Design of Lehigh University Golf Facilities
}

\begin{abstract}
Every year since 1998 as part of the Integrated Learning Experience (ILE) program at Lehigh University, multidisciplinary student teams have designed new athletic facilities including golf, cross country, crew, tennis, lacrosse, soccer, field hockey, softball and baseball. The unique aspect of these designs is that the facilities are realistic projects, some being initial feasibility studies, and some have subsequently been constructed. The 1998 design of a $\$ 2.4$ million, 2000-seat stadium was the first facility to be built. The latest facility to be constructed, and the focus of this case study, is a nine-hole golf course, club house, and driving range. Over a period of six years, three studies involving more than 30 students in 16 majors participated in the planning, designing and financial evaluation of this proposed facility. The 2000 study focused on the design a clubhouse, a land development plan and a detailed business plan. The project evolved, as it often does in a real world environment, and the next two studies added a 3D computer model of the proposed driving range, an irrigation system as well as a design and feasibility study for an executive 9-hole golf course. Groundbreaking commenced in 2006 based on these designs, and will provide an aesthetically pleasing grand entrance to the Goodman Athletic Campus. The unique learning environment allowed students to experience the advantages and challenges of working with practitioners of different backgrounds. Students obtained valuable cross disciplinary undergraduate education and interaction, not typically available to students, which will be invaluable in the real world environment. Teaching and learning challenges of interaction with coaches, facilities and renovation staff, alumni, city officials and other experts created a real world atmosphere. Student presentations were evaluated and assessed by instructors, other university faculty and staff, alumni, including potential donors, and the golf coaches and team. A more formalized assessment program is recommended for future courses. The student participants of these projects have found this experience to be one of their most valuable and memorable at Lehigh.
\end{abstract}

\section{ILE Overview, Course Philosophy and Purpose of the Project}

\section{A. Integrated Learning Experience (ILE) Overview}

Every year since 1998 students from all three undergraduate colleges at Lehigh University have participated in a multidisciplinary project to design new athletic facilities; the three golf facility designs are the focus of this case study. The course idea was created by Drs. Joseph Sterrett, Dean of athletics and Vincent Munley, chair of the Economics Department at the time. The goal was to present a new athletic facility design and use it as a springboard to make it a reality. As a real design team would be assembled from members with different backgrounds, team members were selected from all three undergraduate colleges in the following majors: accounting, architecture, business, chemical engineering, civil engineering, environmental science, economics, finance, history, industrial engineering, international relations, journalism, marketing, mechanical engineering, psychology and supply chain management. They were 
encouraged to use all resources available, both inside and outside their own college and the university. In 2000 the first challenge was to design a clubhouse with a land development plan and a detailed business plan for the facility. Over the next five years and two studies the project evolved, as it often does in a real world environment, by adding $3 \mathrm{D}$ computer models of the proposed driving range and irrigation system and a design and feasibility study of an executive 9-hole golf course. Groundbreaking commenced in 2006 based on these designs, and will provide a unique facility with a challenging layout and beautiful views. The new golf facility will provide a new aesthetically appealing grand entrance to the Goodman Athletic Campus and transform bland cornfields into a valuable introduction to Lehigh's commitment to a state-of-the-art student athletic facility.

Real world teams commonly are composed of members with diverse backgrounds in order to address a complex challenge. Teaching and learning challenges of interaction with coaches, facilities and renovation staff, alumni, city officials and other experts created a real world atmosphere. Student presentations were evaluated and assessed by instructors, other university faculty and staff, alumni, including potential donors, and the golf coaches and team. This realistic environment was analogous to interactions with coworkers, superiors, clients, town officials, and the general public. The students of these projects have found this experience to be one of their most valuable and memorable at Lehigh while giving them a chance to truly leave their mark on their Alma Mater.

This paper focuses upon the processes rather than the results and how the two subsequent studies built upon the previous ones. Copies of the three project reports are available from the authors ${ }^{1,2,3}$.

\section{B. Learning Objectives}

Upon completion of this course the student should be able to:

1. Work effectively as a member of an interdisciplinary project design team, bringing unique skills perspectives and background not shared by all team members, and using information provided outside the student's own background to complete the design.

2. Carry out a sports facility design including the evaluation of considerations such as economics, ethics, societal, environmental impacts, and constructability.

3. Write a project report that is of a quality commonly found to be acceptable in the engineering profession.

4. Orally present the results of an engineering design project to a wide audience of students, faculty, staff, including coaches and student athletes, using a presentation package such as PowerPoint that is of a quality commonly found to be acceptable in the engineering profession.

When students are brought together from many different majors, it poses many interesting challenges and possibilities. Each student is required to participate in one team related to their background and one not related. This allows for students to take a lead on some portions of the project while still playing an integral role and learning about other unfamiliar fields. Students are also posed with the challenge of compiling a 
comprehensive report which is both an academic exercise and a marketing project. This project and similar ones allow students to truly get a real life project experience that may become a reality. Real world problems are addressed and hurdles overcome allowing students to prepare for their first job and have an advantage over the competition.

\section{Assembling a Team}

The students were chosen to address the tasks necessary to reach a common goal of providing a much needed golf facility at Lehigh University (see Table 1). Assembling and managing such a unique team is a difficult task given the expertise required. The number of students in each major was determined by the course instructors, and students were recruited to provide a balanced team to address all of the necessary facets of the project. In some cases department faculty interviewed students and asked them to submit statements as to why their qualifications suited them to the project, selecting a few students from a pool often three or four times the number needed. Some students were interested because they were affiliated with the sport complex being designed and others who heard about the great experience from previous years. Each year had separate tasks and therefore required a specific skill set to address the tasks. The 2000 and 2003 ILE teams required significant expertise in civil engineering and economics because the project tasks were based on an initial land survey and cost analysis which were started in 2000 and updated in 2003. The 2005 ILE team focused more on a business plan for constructability, and architecture.

\section{2000: The Beginning}

\section{A. The Need for a University Golf Facility}

For over 20 years, Lehigh University has striven to better serve the athletic needs of students, faculty, and staff through improvements to the underdeveloped Goodman Campus. The 600-acre Goodman Campus houses a football stadium, a basketball arena, a cross country course, a running track, a field house, multiple tennis courts, and softball, baseball, field hockey, and lacrosse fields as well as numerous practice fields. The university determined that a golf facility would greatly enhance the campus.

Goodman campus' lack of golf facilities forces the men's and women's golf teams travel to other courses to practice and compete. Students, faculty, and staff often chose to drive golf balls in an open area of Goodman campus raising safety concerns for runners using these same open fields. The needs of the Lehigh community were identified and the Integrated Learning Experience (ILE) 2000 team conducted the feasibility analysis for constructing a driving range on Goodman Campus.

The ILE 2000 team was charged with the challenge of becoming a consultant to the university. They were asked to research the design of driving ranges, on-site conditions, local codes, university support, and the cost of construction and maintenance. The research was used to develop site plans, a final report, and presentation to the university. 
Table 1. List of students in the three project teams; team leaders and co-authors of this paper shown in bold.

\begin{tabular}{||l|l|c||}
\hline \multicolumn{1}{|c|}{ Name } & & $\begin{array}{c}\text { Project } \\
\text { Team }\end{array}$ \\
\hline Jennifer Caffrey & Civil Engineering & $\mathbf{2 0 0 0}$ \\
\hline Eric Kuezynski & Civil Engineering & 2000 \\
\hline Shannon Miller & Economics \& English & 2000 \\
\hline Julie Paretchan & Economics \& International Relations & 2000 \\
\hline Jason Snyder & Chemical Engineering & 2000 \\
\hline Drew Tanenbaum & Economics & 2000 \\
\hline Tara Troy & Civil Engineering & 2000 \\
\hline Josh Wood & Architecture & 2000 \\
\hline Michael Zampella & Economics & 2000 \\
\hline Benjamin Cooper & Economics & 2003 \\
\hline Jason Esselen & Accounting & 2003 \\
\hline Tom Gentis & Civil Engineering & 2003 \\
\hline Stephen Giordano & Marketing \& History & 2003 \\
\hline Jessica Gorske & Civil Engineering & 2003 \\
\hline Kristopher Lengieza & Civil Engineering & $\mathbf{2 0 0 3}$ \\
\hline Kathryn Lynch & Civil Engineering & 2003 \\
\hline Erik Morris & Economics \& International Relations & 2003 \\
\hline Nur-E Rahman & Economics \& Journalism & 2003 \\
\hline \hline Karilyn Anderson & Accounting \& Engineering & 2005 \\
\hline Zachary Baron & Architecture & 2005 \\
\hline Danielle Brock & Civil Engineering & 2005 \\
\hline Kevin Deger & Supply Chain & 2005 \\
\hline Kevin Frost & Economics & 2005 \\
\hline Robert Hampson & Civil Engineering & 2005 \\
\hline Kevin Hartmann & Finance \& Engineering & 2005 \\
\hline Jeff King & Architecture & 2005 \\
\hline Daniel Norelli & Mechanical Engineering \& Economics & 2005 \\
\hline Joe Raniszewski & Civil Engineering & 2005 \\
\hline Eric Rimsky & Psychology & 2005 \\
\hline Adrienne Roth & Economics & 2005 \\
\hline Jennifer Vigdor & Journalism \& Business & 2005 \\
\hline Jason Zimpfer & Civil Engineering & \\
\hline \hline & & 205 \\
\hline
\end{tabular}

Introducing an educational golf facility to Lehigh University would be beneficial to the university as well as the surrounding community. The facility would help serve the golf team as well as students of the university and local institutions. With golf being such an important part of business in the $21^{\text {st }}$ century, adding golf education at Lehigh would be invaluable. This facility will also help local schools with practice facilities and instruction. From a need stand point, the facility will only help take the University to the next level to complement the varsity team sport on the collegiate level and also on the local community level. 


\section{B. Goals and Objectives}

The first objective of the ILE 2000 project team was to make a recommendation to the university on the best location for a driving range. Three possible locations on Goodman Campus had been identified previously that allowed the future expansion of the driving range into a more comprehensive golf facility. The Site Development Team considered proximity to major roads, future expansion, safety, and earth moving cost for site selection. Close access to the public Seidersville Road along the boundary of Goodman Campus was a major factor for recommending that site. The other site options required road improvements at a significant additional cost. Once the site was selected, the Survey Team worked together to conduct a topographic survey of the property using one of Lehigh's total stations. The field data was recorded into a field book and entered into AutoCAD Land Desktop software package which was used to generate contours from the survey points, allowing an efficient and accurate cut-and-fill analysis. Other site information included soil samples.

Other teams researched local driving ranges in the area and driving ranges at comparable universities to determine optimum size of the driving range, the number of tees, and the amount to charge for a bucket of balls, none of which was prescribed by the university. Certain assumptions were then made to facilitate final recommendations.

Bethlehem City regulations for the required setbacks, parking size, etc were established and used for the design of the driving range, a small club house, parking lot and bus turnaround. As with every realistic land development project, cost played a big role in the design to make an informed decision. The team obtained cost estimates from local experts as to construction cost, equipment cost, and maintenance cost.

\section{The Team}

The ILE 2000 team was comprised of nine undergraduate students majoring in architecture, chemical engineering, civil engineering, and economics, with second majors of English and International Relations (see Table 1). Each member participated in two or three of the sub-groups to focus decision making of the diverse members (see Table 2). Crucial project decisions were often discussed at the weekly project meeting, but everyday decisions were handled within the sub-group. Appendix A provides a sample weekly progress report from 2005; a similar one was used for other years.

\section{Where Do We Go From Here?}

The ILE 2000 team prepared a written report of their findings and prepared an oral presentation. A design for the driving range, club house, and parking lot was presented to university officials and community members for their consideration. Recommendations were made as to areas to consider for further study, for example the need and cost of adding site lighting. 
Table 2. Project teams involved in the 2000 study

\begin{tabular}{|l|l|}
\hline Survey: & $\begin{array}{l}\text { Perform a topographic survey, use data to locate features of the driving range } \\
\text { facility, and perform a cut-fill analysis. }\end{array}$ \\
\hline Soil Analysis: & $\begin{array}{l}\text { Evaluate soil properties at the site, determine if limitations exist, and make } \\
\text { recommendations for controlling site runoff. }\end{array}$ \\
\hline $\begin{array}{l}\text { Site } \\
\text { Development: }\end{array}$ & $\begin{array}{l}\text { Analyze the utility needs of the driving range facility, specify utility connection } \\
\text { locations, and provide recommendations for future utility expansion. }\end{array}$ \\
\hline Architecture: & $\begin{array}{l}\text { Create a complete three-dimensional plan for an aesthetically pleasing and } \\
\text { functional clubhouse. }\end{array}$ \\
\hline Technology: & $\begin{array}{l}\text { Investigate the technology needs and limitations regarding the driving range } \\
\text { clubhouse. }\end{array}$ \\
\hline $\begin{array}{l}\text { Executive } \\
\text { Course: }\end{array}$ & $\begin{array}{l}\text { Research several parcels adjacent to the driving range site to determine if } \\
\text { expanding the driving range into a } 9 \text { or 18-hole golf course is feasible. }\end{array}$ \\
\hline Cost: & $\begin{array}{l}\text { Identify a driving range equipment company, a land maintenance company, and } \\
\text { a construction company. Use selected companies to generate cost estimates. }\end{array}$ \\
\hline $\begin{array}{l}\text { Benefits/ } \\
\text { Revenue: }\end{array}$ & $\begin{array}{l}\text { Formulate a recommendation of all potential benefits a golf facility could } \\
\text { provide the Lehigh Community and create a business plan. }\end{array}$ \\
\hline
\end{tabular}

\section{2003: We Might Have Something Here}

After the success of the 2000 team presentation and report, the university decided to continue with the development and analysis of a possible golf facility, taking the evaluation to the next level, adding cost evaluations, grading plans and 3D models as well as irrigation considerations. The 2003 team was challenged with taking the existing information and expanding upon it to create a more complete package.

\section{A. How To Pick Up Where the 2000 Study Left Off?}

Imagine being into your boss's office and being handed a binder with a report on a proposed driving and the list of team members to assemble from different divisions of the company. This is very much like being involved in the 2003 ILE project with only the supervising faculty providing continuity because all students had graduated. Analogous to a real world project, the team was provided a starting point and an ending point but the journey was up to them. When team members met for the first time, copies of the original report were issued and discussed as a prelude to advancing the study. Based on recommendations from the 2000 report, an analysis of site lighting and costs was added to the evaluation. Equipment and operating costs were expanded and a site grading and irrigation plan were added.

\section{B. Additional Goals and Objectives}

After deciding to address the issues raised at the end of the first report, it was obvious that additional information was needed and that additional goals were necessary to be set. It was decided to add additional surveying and 3-D modeling of the proposed site as well as an irrigation pond study. These items would help create a rendering which would 
allow for this project to come to life. With the use of 3-D modeling and surveying the students were able to create a realistic visual representation of what the range could look like. They were also able to calculate rough cut-and-fill estimates to project the cost of building the range. There were also several students who studied possible locations of an irrigation pond and the difficulties of working in the limestone region of the Lehigh Valley, much of it susceptible to sink holes, including the Lehigh sports campus. With the goals and objectives set, the team went forward in order to fulfill the needs of the study.

\section{A Marketing Tool?}

The university was strongly committed to moving forward by continuing the design of a golf facility. This made this presentation and reports an integral part of the marketing of this new facility. The students knew from the beginning of the study that the 2003 report would be shown to benefactors, donators, alumni and possibly the future architect and engineer as a starting point for the final design. This provided a unique opportunity for many of the engineering students to work on a team focusing on marketing. The journalism major and marketing majors created a flashy report and presentation that included design data and visual renderings of the future project to help bring the facility to life. The cross disciplinary efforts truly showed how important this class is as it was many of the students first opportunity to work alongside students from a different department and serve as support staff in order to learn the necessary background to make an effective marketing presentation.

\section{Want vs. Need}

With the program for this facility not completely defined, it was necessary to determine which items on the wish list of the university and the golf team were necessary and which were just not feasible. The facility is based around teaching because golf is an integral part of business. The basic design provides the necessary components required by the golf team, having durable components that are simple yet adaptable for players of all levels, including both men's and women's golf teams. The engineers in the group designed the "behind the scenes" infrastructure such as the sprinkler/irrigation and integrated the driving range into the existing landscape to minimize cost.

\section{Is this feasible?}

After careful study, the 2003 team recommended that the project be taken to the next level: "This project would not only be feasible, and recommended, but would also greatly benefit the Lehigh University community." Additional work was necessary to finalize the land grading plans and site planning. From a financial standpoint, although the facility works because it is not required to be profitable, profitability would be a bonus, with moderate use charges to students of the university and surrounding schools as well. Many students and faculty were very optimistic that the report would encourage the university to take the next step for implementing the facility. 


\section{The Team}

The ILE 2003 team was comprised of nine undergraduate students majoring in accounting, civil engineering, economics, history, international relations, journalism, and marketing (see Table 1). Each member of the team participated in two or three of the project sub-groups. These sub-groups helped to focus decision making with the diverse student team. Crucial project decisions were often discussed at the weekly project meeting, but everyday decision could be handled within the sub-group. Table 3 shows the eight teams and a description of their tasks.

Table 3. Six project teams of 2003 study

\begin{tabular}{|l|l|}
\hline Survey: & $\begin{array}{l}\text { The group focused on providing an accurate survey of the proposed location } \\
\text { as well as a proposed 3-D model of the design of the facility. The pond } \\
\text { design and location were also integrated into this design. }\end{array}$ \\
\hline Ponds: & $\begin{array}{l}\text { Study and design an irrigation pond and its location analyzing irrigation } \\
\text { needs as well as possible problems with limestone deposits in the area. }\end{array}$ \\
\hline $\begin{array}{l}\text { Benefits/ } \\
\text { Education: }\end{array}$ & $\begin{array}{l}\text { Examine the benefits of the facility and its uses for an educational facility. } \\
\text { Also included surveying of students and faculty. }\end{array}$ \\
\hline Costs: & $\begin{array}{l}\text { Determine if the facility was cost feasible by looking into operating costs } \\
\text { and comparing this to the projected revenue provided by the revenue group. }\end{array}$ \\
\hline Pricing/Revenue: & $\begin{array}{l}\text { This group surveyed students and faculty in order to determine the usage of } \\
\text { the facility. The team also analyzed local facilities in order to determine } \\
\text { the market value of the facility. }\end{array}$ \\
\hline Report Group: & $\begin{array}{l}\text { Create a comprehensive business plan based on the required information } \\
\text { from the other groups to complete the mission statement }\end{array}$ \\
\hline
\end{tabular}

\section{2005: A Vision Becomes a Reality}

\section{A. How do we produce a constructible product?}

The four main topics that were crucial in guiding our business plan to turn the facility into a constructable product, without going into great detail about the work completed by each team are presented in this section.

1. Market Analysis:

Performing a market analysis for a golf facility was important to success in creating a usage projection and financial model, as well as confirming interest of many different groups of the Lehigh community. We identified that our two biggest competitors are neighboring courses in the Lehigh Valley and other universities with college-owned courses. We examined our local and collegiate competitors and collected information from them to help identify Lehigh's target market. Lehigh's market of users is narrow since the golf facility will only be open to those within the Lehigh community, which can be loosely defined as students, faculty, staff, alumni and guests. We analyzed each segmented group of users and considered their potential golf facility usage behavior. Through surveys, interviews, past performance statistics and research, we examined the 
market and obtained usage projections for each segmented group and varied the projections based on the time of day and year.

\section{Designed Features:}

Past ILE teams conducted research and proposed pond requirements, irrigation system and clubhouse design based on the golf course site that previously shared ground with Lower Saucon Township and Bethlehem City. However, the 2005 ILE team found that the course needed to be located entirely in Lower Saucon Township because of political and approval constraints. As a result, the course had to be redesigned in order to be within the township boundaries before any design or irrigation system could begin.

The 2005 ILE team redesigned the 9-hole course layout, and independently designed a pond, irrigation system and clubhouse, complete with the requirements and constraints. All designed features were developed on an iterative process with each iteration being presented to a professional in its respective field. For example, the Clubhouse Design team made physical models that they presented to Tony Corallo, Associate Vice President of Lehigh's Facility Services, throughout the semester to gain feedback that they could implement in their next iteration.

As stated earlier, the overall implementation and construction cost, funded by an alumnus, wasn't the main focus of our project. Instead we identified all costs related to the operation and maintenance (O\&M) of a golf course. The costs we determined are categorized into three subgroups: Course and Range Costs, Clubhouse Costs, and Pond and Irrigation Costs. The Course and Range Costs are almost entirely composed of landscaping costs, and the miscellaneous costs are the annual costs of replacing supplies and an insurance policy for the course. The Clubhouse Costs include personnel, utilities and supply replacements costs. Finally, the Pond and Irrigation Costs include the annual cost of maintenance and electricity to pump the water.

\section{Pricing Strategy and Revenue Projections:}

A pricing strategy was developed consisting of three cases: competitive case, breakeven case and university value case. The competitive case sets the prices that were determined from market research of local golf courses, national university courses, and the input from our various surveys. The break-even case sets the prices necessary to create a revenue projection that breaks-even with the determined annual costs. The university value case is similar to the competitive case expect with a subsidized price for alumni and no fee for Lehigh students.

For each, weekday and weekend prices were determined, and from Market Analysis usage projections, we calculated revenue for each pricing strategy to determine how close each scenario came to covering the projected annual costs of the designed features. If the annual revenue did not cover the annual cost, then as estimate was made for the necessary initial endowment earning 5\% interest that would be needed to break even.

Presenting three pricing strategies was important information when presenting to Lehigh officials involved in the decision process to build the facility because they were 
able to see that for the projected costs of the proposed designs and the projected usage of the facility, the prices didn't need to inflate drastically in order for the facility to operate without additional funds from the university. This was seen by comparing competitive and break-even prices. Also, determining the necessary initial endowment if competitive prices wanted to be used gave Lehigh officials a gauge to how feasible raising such funds would be.

\section{Value Statement}

Aside from the financial feasibility analysis of the facility, a key portion of the report was dedicated to the added value Lehigh University would get for implementing the nine-hole executive course and driving range. The Lehigh golf facility will bring an intangible value to Lehigh's golf team, the university and athletics program, and the Lehigh community. The addition to Goodman Campus will become a permanent landmark for Lehigh University, and offer the opportunity for Lehigh and its athletics program to achieve greater visibility regionally, nationally and internationally. It will provide a home for Lehigh's Varsity Golf team and aid in improving their competition and recruiting process with other teams. As well, it will give Lehigh a competitive advantage in Lehigh admissions by comparing our athletic facilities with other topranked institutions.

Upon completing our analysis, we felt that our work would provide as a solid framework for Lehigh Officials to decide whether to implement this concept into a reality. We were able to provide a feasible design for a nine-hole course that met the zoning restrictions of Goodman Campus. Included in this design was a pond and irrigation system that was proven through various calculations to store a sufficient amount of water and provide adequate transfer of water to all areas of the course. We were also able to design a Clubhouse that meets the needs of an indoor practice facility during winter months while aesthetically fitting into Goodman campus. Most importantly, we were able to show in great detail how the operation and maintenance costs associated with these designed feature could be offset by revenue projections calculated using various pricing strategies and usage projections from market analysis. This information along with a value statement make it easy to see how a concept can be turned into a reality.

\section{B. The Team}

The 2005 ILE team, consisting of 14 members from 9 different undergraduate programs, was faced with a slightly different task then the previous ILE teams (see Table 1). Since 2000, ILE teams have conducted market research, evaluated facility needs and developed cost projections. In the summer and fall of 2002, an interested alumnus agreed to help Lehigh University advance the golf course concept into a tangible project. With a donor secured, ILE teams ventured even further in continuing to evaluate all aspects of the facility. Even though the entire development and construction cost will be externally funded, the 2005 ILE team was charged with developing a detailed business plan for the operation and maintenance of the 9-hole executive golf course and driving range, continuing the previous research and defining the following objectives: 
- Design a pond, irrigation system, clubhouse and signage for the golf facility

- Determine annualized operation and maintenance costs of the facility

- Determine golf facility usage projection

- Create various pricing strategies and revenue projections

- Generate a value statement for Lehigh University

The 2005 report is providing the basis for construction of the new golf complex. The first step of the business plan for operation and maintenance was to define the mission statement and objectives, and then break the group into teams to focus on completing specific objectives. Table 4 lists the eight teams and their major tasks for the 2005 study.

Table 4. Project teams of 2005 study

\begin{tabular}{|l|l|}
\hline $\begin{array}{l}\text { Project } \\
\text { Management: }\end{array}$ & $\begin{array}{l}\text { Plan and coordinate resources and tasks to achieve objectives and goals } \\
\text { outlined in mission statement. Create communication protocols for all team } \\
\text { members. }\end{array}$ \\
\hline $\begin{array}{l}\text { Market } \\
\text { Research: }\end{array}$ & $\begin{array}{l}\text { Study and research market to project the golf course usage by target and } \\
\text { secondary markets. Conduct a demographic profile, investigate the habits } \\
\text { of the target customer, and research competitors. }\end{array}$ \\
\hline Pond Design: & $\begin{array}{l}\text { Create a functional layout of the overall pond system based on background } \\
\text { research of pond characteristics and desired location and design. Find } \\
\text { maintenance and supply requirements and utility costs. }\end{array}$ \\
\hline $\begin{array}{l}\text { Irrigation } \\
\text { Design: }\end{array}$ & $\begin{array}{l}\text { Examine estimates of water quantity and create a functional layout of the } \\
\text { overall irrigation system including costs. Research current irrigation } \\
\text { systems, generate sketches and models, and find maintenance and supply } \\
\text { requirements and utility costs. }\end{array}$ \\
\hline $\begin{array}{l}\text { Clubhouse } \\
\text { Design: }\end{array}$ & $\begin{array}{l}\text { Create scaled model of the clubhouse with a fully functional layout. } \\
\text { Discover the technical and financial feasibility of the design, and research } \\
\text { the maintenance, managerial and utility costs. }\end{array}$ \\
\hline Pricing Strategy: & $\begin{array}{l}\text { Determine a pricing strategy based on customer needs, cost analysis, } \\
\text { comparative prices and projected revenue. Develop formulas to complete } \\
\text { an analysis for three pricing strategies. }\end{array}$ \\
\hline Cost Analysis: & $\begin{array}{l}\text { Assemble an overall cost analysis and create a time-line of the replacement } \\
\text { and annual costs. }\end{array}$ \\
\cline { 2 - 3 } Report Group: & $\begin{array}{l}\text { Create a comprehensive business plan based on the required information } \\
\text { from the other groups to complete the mission statement }\end{array}$ \\
\hline
\end{tabular}

\section{Meeting and Exceeding ABET Requirement}

\section{A. Accreditation of Engineering Programs}

ABET, Inc. (previously the Accreditation Board for Engineering and Technology) is the recognized organization responsible for accreditation of over 2700 education programs in applied science, computing, engineering, and technology at over 550 colleges and universities in the USA. According to $\mathrm{ABET}^{4}$ their federation of 30 professional and technical societies is among the most respected accreditation organizations in the U.S., and in turn is recognized by the Council for Higher Education Accreditation, providing 
leadership and quality assurance in higher education for over 70 years. By involving the professional societies, ABET accreditation assures that a program will meet the quality standards established by the applicable profession. ABET indicates the most important reasons for accreditation as:

- Helps students and their parents choose quality college programs.

- Enables employers to recruit graduates they know are well-prepared.

- Is used by registration, licensure, and certification boards to screen applicants. Accreditation gives colleges and universities a structured mechanism to assess, evaluate, and improve the quality of their programs.

\section{B. ABET Accreditation Requirements}

Several of the eight main ABET criteria for engineering programs ${ }^{4}$ explicitly address the kinds of skills that are satisfied by interdisciplinary, team-based courses. The ILE courses contribute to the satisfaction of all parts of Criteria $3, a$ through $k$, except for parts b and I; specifically they contribute to the following:

Engineering programs must demonstrate that their students attain:

a. an ability to apply knowledge of mathematics, science and engineering

c. an ability to design a system, components or process to meet desired needs with realistic constraints such as economic, environmental, social, political, ethical, health and safety, manufacturability and sustainability

d. an ability to function on multi-disciplinary teams

$e$. an ability to identify, formulate and solve engineering problems

$f$. an understanding of professional and ethical responsibility

$g$. an ability to communicate effectively

$h$. the broad education necessary to understand the impact of engineering solutions in a global economic, environmental, and social context

j. a knowledge of contemporary issues

$k$. an ability to use the techniques, skills, and modern engineering tools necessary for engineering practice

This case study describes the contribution of the ILE course toward these criteria and required skills, including a review of the assessment and evaluation methods used to measure and assess the students' performance, and to recommend new assessment methods in future ILE sports courses to improve assessment.

ABET defines design in Criterion 4 as the process of devising a system, component, or process to meet desired needs. ABET requires that design be integrated throughout the curriculum (Criteria $4 \mathrm{a}$ and $4 \mathrm{~b}$ ), culminating in a major or capstone design experience (by the last sentence under Criterion 4c): Students must be prepared for engineering practice through the curriculum culminating in a major design experience based on the knowledge and skills acquired in earlier course work and incorporating engineering standards and multiple realistic constraints.

The original EC2000 (Engineering Criteria 2000) regarding capstone design under Criteria 4 was more stringent, e.g. the last three words of Criterion $4 \mathrm{c}$ listed above, 
multiple realistic constraints, originally read: realistic constraints that include most of the following considerations: economic; environmental; sustainability; manufacturability; ethical; health and safety; social; and political. The list of realistic constraints now appear under Criterion 3c, and is weaker now because (1) they can be satisfied by work in any course (not required under the capstone design) and (2) is just a suggested list rather than having a requirement that most be included

Also, because the requirement for multiple disciplines is included under Criterion $3 \mathrm{~d}$ : Engineering programs must demonstrate that their students attain an ability to function on multi-disciplinary teams, it can be satisfied by course work other than the capstone design and the multi-disciplinary criterion is weaker than interdisciplinary, e.g. it can be satisfied by teams in different sub-areas of the same program. For example, for civil engineering programs, Criterion $3 \mathrm{~d}$ can be satisfied by two civil engineering subdiscipline teams, one in structural engineering and the other in soil mechanics. ABET felt that an interdisciplinary teaming requirement would be difficult to include because it relied on cooperation with other department or programs and perhaps beyond the control of the accredited program. Also, many programs expand upon the design requirement by including design criteria under Criterion 8 , additional criteria for individual programs. For example, the civil engineering program criteria include: The ability to perform civil engineering design by means of design experiences integrated throughout the professional component of the curriculum and "The program must demonstrate that faculty teaching courses that are primarily design in content are qualified to teach the subject matter by virtue of professional licensure, or by education and design experience.

\section{Exceeding the Minimum ABET Design Requirements}

Interdisciplinary teams are not now required by ABET, provided the program can demonstrate that somewhere in the curriculum students function on a multidisciplinary team, e.g. teams on different sub-disciplines in a single major. In the ILE (Integrated Learning Experience) model for designing sports facilities, we exceed the minimum ABET requirements of a capstone course by exceeding the more stringent, original EC 2000 statement of: include most of the following considerations: economic; environmental; sustainability; manufacturability; ethical; health and safety; social; and political in the major culminating (capstone) design course. Engineering students are not just role playing to cover the various required non-engineering disciplines, but rather they are assigned to teams in their major area of expertise, working directly with students in non-engineering majors from a wide variety of majors.

Also, our teams are truly interdisciplinary, not just having students in one major roleplaying other disciplines, either multidisciplinary or interdisciplinary. And we require teaming as a part of the major design experience and not just satisfied somewhere in the curriculum.

The new product development process (see Fig. 1) used by the Integrated Product Development (IPD) program, was applied by the authors to the studies. The first two teams were involved in Phase 1 and the 2005 team was involved in both Phases 1 and 2 . 


\section{Project and Process Management}

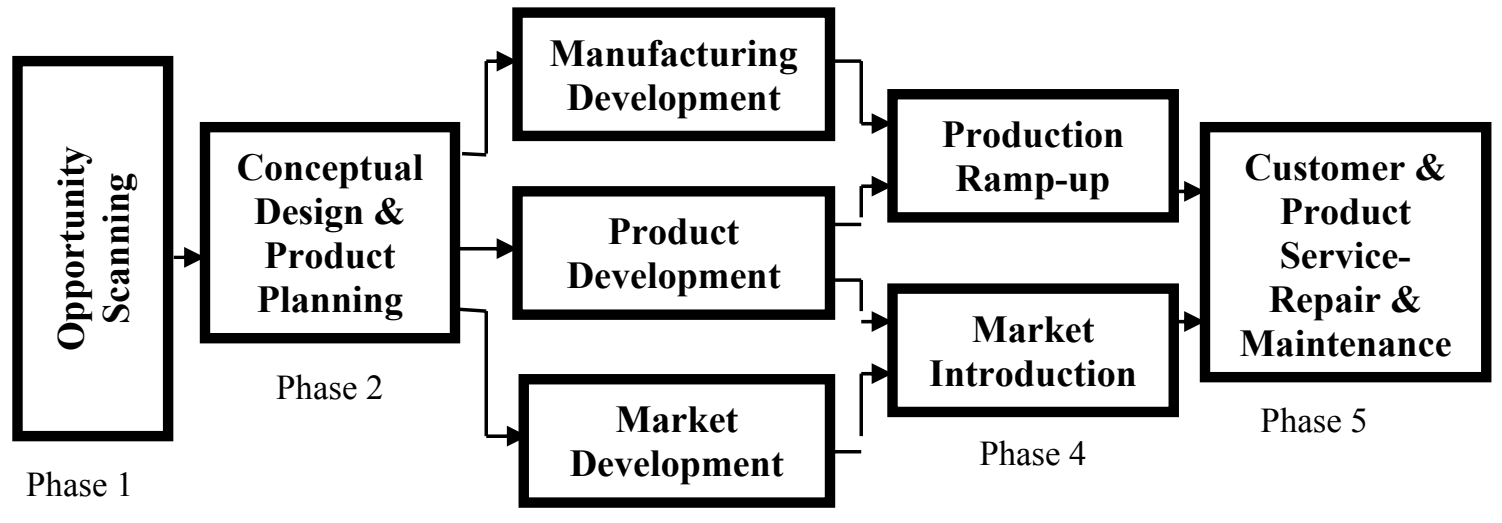

Phase 3

\section{Documentation and Data Management}

Figure 1. New Product Development Process as Modeled in Lehigh's IPD Program

\section{Teaching and Learning Challenges}

\section{A. Early Course Formation and Challenges}

In 1998, the course instructors performed the first sports facility study, that being a single 2000-seat central stadium with an artificial turf field on one side, a natural turf on the other, each able to accommodate a variety of sports, including field hockey, lacrosse, and soccer. The instructors reviewed the current sports facilities and projected needs, selected a topic, worked with the coaches of various sports who acted as the client(s), recruited a group of faculty advisors in each of the home departments who were willing to supervise the individual students, helped arrange support from the university facility services (blue prints, topographic maps, utility information, etc), and helped provide the

resources beyond the ability of the students to obtain, such as real pricing from actual construction companies, clearance for issues such as candidate sites for projects, and realistic budget. They also often made public announcements, and arranged for students to present one of the projects to the Lehigh University Board of Trustees, and helped arrange for a truly broad audience that included upper-level facilities staff, coaches, external contractors, and potential benefactors. The instructors had to continually monitor the progress of the interdependent teams, and redefine roles if needed. Peer evaluations and periodic monitoring helped faculty assess student performance for evaluation and issuing of grades and to identify slackers.

The most common group interaction challenge was how to handle a domino effect when a team missed a deadline for providing information to other teams who in turn could not 
move forward without that information. Students are often geared for a weekly reading of the textbook and homework with a periodic test. Their time management skills are often challenged when the deliverable is a presentation is not for seven weeks on a vaguely defined project, for which only part of the identified tasks will be handled by themselves. It is a learning experience on how to get started, identify and state aspects of the study normally provided as given information, stay focused and on target, and meet deadlines. Because it was often early in the process, the architecture team occasionally missed the agreed-upon deadline (often the seventh week) for submitting the design in time for the mid-term presentation. Although this occurred to some extent in the golf studies, it was a significant issue in a different year when another sports complex was studied. That year, although pressured to finalize the design, the architecture team did not provide the information until several weeks later, in time to make a sound architectural presentation in the last (fourteenth) week, but was so late into the study that a "rush job" were done on several aspects of the civil engineering and economic component, and some of the information was not exchanged in a timely manner.

The faculty instructors, and faculty advisors when appropriate, had to walk a fine line in project management issues for such cases, choosing between three basic options:

1. let students work out the issues with possible detriment to course or deliverables

2. provide limited executive decisions to positively affect the outcome(s)

3. weigh in heavily and interrupt the interactions that might work themselves out in a timely manner by the students

Such decisions were difficult at times, and Option 3 would typically result in a better deliverable but a less valuable student learning process. The faculty instructors used such cases as real learning experiences, and encouraged groups such as the architectural group to reflect on the situation afterward and to appreciate the negative impact on the overall project when Option 1 was used and deadlines were missed.

The learning experience that came out of this challenge was great, even from the frustration of the civil engineering students; they certainly arrived on the job market much wiser with first hand knowledge experience of project management issues. The students appreciated the helplessness of not being able to conduct their task and mission because of dependency on another team, and they could not obtain the information on their own. One of the students reported that during a successful job interview, a significant part of the time was spent discussing the lessons learned from true, in depth, interdependency in the work place.

The instructors used valuable experiences with each of these options to develop a more structured system of creating a process that insisted on deadlines as part of the process as opposed to remedial action as needed.

Because of the great benefit to the students, several parallel (non-golf) projects were run in the ILE course one year. However, because these ILE courses were largely an addition to normal teaching duties, the teaching, leading, and advising about 40 students in simultaneous multiple studies, each consisting of eight or so teams, was not a feasible 
long term strategy. Since then, each fall a single project with ten to fifteen students was conducted, with a follow-up project in the spring as needed.

\section{B. Addressing the Challenges}

The 2000 study mainly focused upon civil engineering and economics, and the coordination was not as challenging as subsequent years, and students and teams interacted well. Since the first two golf studies, as well as those on other sports facilities, the instructional and learning environment was refined. For each of the studies, on a weekly basis, an individual student team would meet together, work on tasks, and then meet with the full class at a project meeting in a large conference room in the athletic facility, a very different atmosphere than traditional courses. Each team had to report on progress they made towards their own goals and on tasks that other teams had requested of them. With the possibility of 10-15 people all wanting to be heard, the possibility existed that one person or team could dominate the floor and exclude critical exchange of information needed by other teams.

The 2005 ILE team consisted of eight subgroups. Each subgroup had a designated group leader who led discussions on subgroup progress when the entire team of thirteen students met. When the team met with the faculty leaders on a weekly basis, the project manager would present the progress of each subgroup and allowed subgroup leaders to elaborate and ask questions to the advisors. Although this seems like a hierarchical system, in worked effectively to ensure all team members knew what was expected of them when the team met and allowed meeting to run efficiently.

A communication protocol was developed at the beginning of the project which laid out the procedure for file sharing within each subgroup and as a team. The 2005 team utilized the Blackboard system available to all Lehigh students which allowed subgroups to create their own virtual database for which members could access information pertaining to their work. The protocol instructed students to call attention to their fellow subgroup member via email when any files were added to their virtual database and also to bring a hard copy of the posted information to team meetings to allow the rest of the team to be aware of what exists on the Blackboard system. This protocol made it easy for all team members to access information in an organized fashion.

When presenting to project advisors and individual student advisors, organized progress reports were presented which laid out the previous week's accomplishments, actions items and the team member responsible, and goals for the upcoming week. An example of a progress report used by the 2005 ILE team is shown in Appendix A. This method and template was borrowed from the IPD department and proved to also work effectively for the ILE team.

What made this project unique to many of the students involved was the time commitment necessary by the entire team in order to create a successful product. The entire team met every week without advisors for two hours and subgroups met at their own scheduled time. The team also met as a whole with advisors once a week for one 
hour. Each individual student met with his/her department advisor varying amounts depending on the advisor. On top of all the meetings and other coursework of a junior of senior college student, each student needed to do the work that was assigned to them for the project. This sometimes required students going out and meeting with professionals, talking with interested students, or crunching hours in the CAD labs. For some students this was the first type of project that couldn't simply be done by looking up information and solving a problem laid out to them by a professor. It required hard work, creativity, and time. These types of projects give students a good sense of want a professional consultant may face when working on a business development project. Most of all, it confirmed the instructors' faith in the work of its students to take a project from a concept and turn it into something real.

\section{Summary of Benefits to Students}

The students have benefited immensely from working across the disciplines, learning to manage time challenges in project work, and experiencing the challenges of making choices, trade-offs, and making assumptions. These are all "life-lessons" that emanate from the technical knowledge base developed in traditional curriculum experience, but also help students transcend their basic understanding of concepts and gain a sense of challenges in applying knowledge to real world projects that must be feasible and stand the test of time.

\section{Conclusion: A Living Lesson}

The advantages of these ILE courses are the key interactions and learning the pragmatic relationship between engineering designs and cost/value considerations. The students have gained meaningful exposure to the practical considerations associated with various design options, including site layout, construction, and functional design such as irrigation, utilities, energy, and material choices not often considered in other courses. Engineering students are not just "role playing" to cover the various required disciplines, but rather, as shown in Tables 1 to 4, there is a rich multiplicity of cross-disciplinary dimensions to the projects, with engineering students working on a wide variety of tasks directly with majors from a wide variety of majors in all three undergraduate colleges, specifically recruited for their background as needed.

Another valuable aspect of this project is that it allows students to come back to their alma mater and see a building or a facility that they helped design. Knowing that their project may be built motivates students to truly pour their efforts into these projects, and can help them envision the effect they can have on the university. These projects is also a huge marketing plus when recruiting students.

Many engineering students are never exposed to real-world cost considerations and actual constructability issues, are "design in a bubble." Many students are skilled in reading a chapter and answering questions on technical information without having to balance it with intangibles. Studies such as the golf studies better prepare engineers with a unique 
opportunity to see the other aspects of designing a project, and all the considerations that need to be taken into consideration, especially real costs.

\section{Recommendations for Future Grading and Assessment}

Grading of all students was conducted in a similar manner; only the civil engineering student grading is described here to give some insight into the process. Dr. Lennon (paper co-author) supervised all civil engineering students from 1998 to 2005 in all ILE sports projects including the golf projects, providing a consistency from year to year. He and other supervising faculty applied their own grading system for the overall oral and written presentations and provided summary grades to the instructors. For presentations, Dr. Lennon adapted the civil engineering capstone design system: each individual speaker is evaluated for Content, including knowledge of the subject, clarity and response to questions, and Presentation where they were evaluated for preparation, effectiveness of visuals, professional style including eye contact. Immediately after the presentation, Dr. Lennon would share his evaluation of all students with the course instructors and provide any comments, sometimes negative, in his area of expertise. When warranted, he would have follow up discussions other faculty; it was common to discuss the performance of the architecture group with the architectural faculty supervisor to reach a consensus about the civil engineers' and architects' performance and each role in the group.

The instructors compile faculty and student evaluations, form their own recommendation, and consult with the individual faculty supervisors. Any differences in evaluations were discussed further, with the instructors often putting the evaluation of a particular supervisor's student in context with the other students.

For the aspects of the design in Dr. Lennon's area of expertise, he would provide a more detailed evaluation to the course instructors. For example, Dr. Lennon was retained as a consultant to an environmental \& engineering consulting firm, in turn hired by a golf design firm, to determine if sufficient water resources existed to maintain irrigation at a proposed 18-hole golf course in Pennsylvania. Dr. Lennon also has interacted with extension service employees for design construction and maintenance of ponds. Dr. Lennon evaluated the students' designs using his own expertise supplemented by input from these professionals, many of whom were contacted by the students and provided feedback to Dr. Lennon. If the students did not address concerns raised by Dr. Lennon in small group meetings, that was considered when evaluating the students' grades.

Throughout the course the instructors and faculty supervisors interacted with the students and were usually aware of any problems with their peers' contribution or performance from these informal avenues. A more formal peer evaluation was conducted at the end of the course, where each student was asked to evaluate what share of a hypothetical financial bonus each student deserved. In 2005, each student had 75 points to distribute among the 14 members, resulting in an average evaluation of about 5.4 points per person. Each of the 14 responses was entered into a matrix so that each student received an 
evaluation. Individual assessments of each other ranged from low of 0 to the high of 10 points allowed; the lowest total evaluation was 52 (3.7 average) and the highest was 113 (8.1 average). Generally, the peer evaluations were consistent with the faculty evaluations, and if not they, they were discussed at length by the faculty. For example, one of the four civil engineering students one year was quietly competent and made a good contribution, but did not convey accomplishments or effort to the team and got a low peer score. The instructors took this into consideration when assigning a final grade to recognize the contribution, but used it as a learning experience to let the student know that being a more forceful would be in the student's best interest.

As described above, the faculty and peer evaluation system has worked extremely well in the ILE sports complex courses over the last decade. However, the authors investigated and recommend that a more formal assessment be performed using a procedure to help provide consistence. The model assessment and evaluation proposed is based on Lehigh's Integrated Product Development (IPD) program, which includes a comprehensive set of rubrics for consistent evaluation of each oral presentation as shown in Table $5^{5}$. The authors have obtained analogous rubrics for the written presentations based on the IPD model.

\section{References}

1. Caffrey, Jennifer, Eric Kuczynski, Shannon Miller, Julie Paretchan, Jason Snyder, Drew Tanenbaum, Tara Troy, Josh Wood, and Michael Zampella, "Integrated Learning Experience: Evaluating and Designing a Golf Driving Range Facility" 2000 ILE class.

2. Cooper, Benjamin, Jason Esselen, Tom Gentis, Stephen Giordano, Jessica Gorske, Kristopher Lengieza, Kathryn Lynch, Erik Morris, and Nur-E Rahman, "Golf Facility Design and Performance Evaluation" Final Report from 2003 ILE Class.

3. Anderson, Karilyn, Zachary Baron, Danielle Brock, Kevin Deger, Kevin Frost, Robert Hampson, Kevin Harmann, Jeff King, Daniel Norelli, Joe Raniszewski, Eric Rimsky, Adrienne Roth, Jennifer Vigdor, Jason Zimpfer, Vincent Munley, and Joe Sterrett, "Lehigh University Golf Course Operation and Maintenance Analysis" Final Report, 2005 ILE Class.

4. Accreditation Board for Engineering and Technology (ABET), Inc. www.abet.org.

5. Getzler-Linn, Lisa, John B Ochs, and Todd A. Watkins. "Program and Student Performance Assessment in Team-Based Project Courses with Focus on Technical Entrepreneurship and Product Development: Lehigh University's IPD Program.” Proceeding from the January 2006 USASBE Conference, Tucson AZ, January 2006.

6. Ochs, John B., Gerard P. Lennon, Todd A.Watkins, and Graham Mitchell. "A Comprehensive Model for Integrating Entrepreneurship Education and Capstone Projects while Exceeding ABET Requirements," Proceedings of the annual meeting of American Society of Engineering Educators, 2006. 
Table 5. Sample rubric used in Integrated Product Development (IPD) ${ }^{5}$ Program to assess final oral presentation; analogous rubric to be used for final report and other course components

\begin{tabular}{|c|c|c|c|c|}
\hline Professionalism & Overall Content & Technical Content & Preparedness & \\
\hline $\begin{array}{l}\text { Presentation was } \\
\text { given in such a } \\
\text { manner that the } \\
\text { students could have } \\
\text { been mistaken for } \\
\text { employees of the } \\
\text { company. }\end{array}$ & $\begin{array}{l}\text { Every topic covered } \\
\text { was well researched } \\
\text { and relevant. } \\
\text { Audiovisual } \\
\text { components } \\
\text { contributed a great } \\
\text { deal to the } \\
\text { presentation. }\end{array}$ & $\begin{array}{l}\text { Introduction of company, } \\
\text { project objectives, market } \\
\text { research, design concepts, } \\
\text { technical \& financial } \\
\text { feasibility \& plans for future } \\
\text { work were all fully discussed } \\
\text { within the time constraints. }\end{array}$ & $\begin{array}{l}\text { Every aspect of the } \\
\text { presentation was } \\
\text { well rehearsed and } \\
\text { every member of the } \\
\text { team was prepared to } \\
\text { speak and answer } \\
\text { questions about their } \\
\text { topic area. }\end{array}$ & exemplary \\
\hline $\begin{array}{lll}9 & 9.5 & 10\end{array}$ & $\begin{array}{lll}9 & 9.5 & 10\end{array}$ & $\begin{array}{lll}9 & 9.5 & 10\end{array}$ & $\begin{array}{lll}9 & 9.5 & 10\end{array}$ & \\
\hline $\begin{array}{l}\text { Presentation was well } \\
\text { done and appropriate. } \\
\text { It had a flavor of } \\
\text { professionalism that } \\
\text { was slightly beyond } \\
\text { the students academic } \\
\text { status. }\end{array}$ & $\begin{array}{l}\text { The topics covered } \\
\text { were presented with a } \\
\text { fair amount of detail } \\
\text { and level of relevance. } \\
\text { Audiovisual } \\
\text { components supported } \\
\text { but did not enhance } \\
\text { presentation. }\end{array}$ & $\begin{array}{l}\text { Introduction of company, } \\
\text { project objectives, market } \\
\text { research, design concepts, } \\
\text { technical \& financial } \\
\text { feasibility \& plans for future } \\
\text { work were addressed with } \\
\text { some detail mostly within the } \\
\text { time constraints. }\end{array}$ & $\begin{array}{l}\text { Most of the } \\
\text { presentation was } \\
\text { prepared and most } \\
\text { team members were } \\
\text { able to speak about } \\
\text { their topic area. } \\
\text { Most questions were } \\
\text { answered. }\end{array}$ & good \\
\hline 8.5 & 8.5 & 8.5 & 8.5 & \\
\hline $\begin{array}{l}\text { Presentation was } \\
\text { given in a manner } \\
\text { consistent with } \\
\text { student behavior. No } \\
\text { level of } \\
\text { professionalism was } \\
\text { attained. }\end{array}$ & $\begin{array}{l}\text { The topics covered } \\
\text { were limited in scope } \\
\text { and depth. } \\
\text { Audiovisual } \\
\text { components were } \\
\text { problematic and } \\
\text { detracted somewhat } \\
\text { from the presentation. }\end{array}$ & $\begin{array}{l}\text { Introduction of company, } \\
\text { project objectives, market } \\
\text { research, design concepts, } \\
\text { technical \& financial } \\
\text { feasibility \& plans for future } \\
\text { work were not all addressed \& } \\
\text { time was not used wisely. }\end{array}$ & $\begin{array}{l}\text { Some of the } \\
\text { presentation seemed } \\
\text { prepared. One or } \\
\text { two team members } \\
\text { dominated; some } \\
\text { members were less } \\
\text { prepared than the } \\
\text { rest. Some ability to } \\
\text { answer questions } \\
\text { was apparent. }\end{array}$ & limited \\
\hline $\begin{array}{ll}7.5 & 7.9\end{array}$ & $\begin{array}{lll}7 & 7.5 & 7.9\end{array}$ & $\begin{array}{lll}7 & 7.5 & 7.9\end{array}$ & $\begin{array}{lll}7 & 7.5 & 7.9\end{array}$ & \\
\hline $\begin{array}{l}\text { Presentation was not } \\
\text { only unprofessional } \\
\text { but below college } \\
\text { level standards. }\end{array}$ & $\begin{array}{l}\text { The topics covered } \\
\text { were not clearly } \\
\text { related to the project } \\
\text { outcome nor were } \\
\text { enough topics covered. } \\
\text { Audiovisual } \\
\text { components were } \\
\text { either scarce or } \\
\text { inappropriate. }\end{array}$ & $\begin{array}{l}\text { There didn't seem to be a full } \\
\text { understanding of the need for } \\
\text { above topics to be included in } \\
\text { presentation. Only a cursory } \\
\text { view of the project was } \\
\text { presented. }\end{array}$ & $\begin{array}{l}\text { The team was not at } \\
\text { all prepared to speak } \\
\text { or answer questions } \\
\text { on the topics relevant } \\
\text { to the project. No } \\
\text { rehearsal was } \\
\text { apparent. }\end{array}$ & deficient \\
\hline $6.5 \quad 6.9$ & 6.5 & $6 \quad 6.5$ & $\begin{array}{lll}6 & 6.5 & 6.9 \\
\end{array}$ & \\
\hline $\begin{array}{l}\text { Raw Scores: } \\
\text { Professionalism Score }\end{array}$ & Overall Content Score: & Technical Content Score: & Preparedness Score: & \\
\hline $\begin{array}{l}\text { Formula: } \\
\text { x } 1=\end{array}$ & $-\times 2=$ & $\times 2=$ & $-\times 1=$ & $\begin{array}{l}\text { Add } \\
\text { across } \\
\text { Total: }\end{array}$ \\
\hline
\end{tabular}




\section{Appendix A}

\section{LEHIGH UNIVERSITY ILE GOLF COURSE PROJECT}

WEEKLY PROGRESS REPORT

\section{WEEKLY MEETING MINUTES:}

Recurring Meeting Dates: Wednesday, 7:30 PM; Friday, 12 PM;

\section{Team Members in Attendance:}

Jason Zimpfler

Daniel Norelli

Adrienne Roth

Joe Raniszewski
Kevin Frost

Zach Baron

Karilyn Anderson

Jeff King
Today's Date: 9/23/05

\begin{tabular}{|c|c|}
\hline Previous Week's Accomplishments & Action Items \& Person Responsible \\
\hline $\begin{array}{l}\text { A) Drafted mission statement and team descriptions } \\
\text { for report. }\end{array}$ & $\begin{array}{l}\text { A) Contact } 5 \text { local golf courses to schedule meetings } \\
\text { or phone interviews (Market Research Team) }\end{array}$ \\
\hline $\begin{array}{l}\text { B) Developed and received approval for student and } \\
\text { industry questionnaires. }\end{array}$ & $\begin{array}{l}\text { B) Determine and rank } 10 \text { specific customer needs our } \\
\text { course needs to satisfy to be competitive in market. }\end{array}$ \\
\hline $\begin{array}{l}\text { C) Contacted and met with Wedgewood Golf Club } \\
\text { manager. }\end{array}$ & $\begin{array}{l}\text { C) Create Rough Draft of Market Research Section of } \\
\text { report: competitors, market presence, strengths and }\end{array}$ \\
\hline Contacted and met with city hall for utility & weaknesses. \\
\hline $\begin{array}{l}\text { E) Worked to almost completion of course layout to } \\
\text { determine yardage estimation. }\end{array}$ & $\begin{array}{l}\text { D) Get individual team task lists and projected } \\
\text { timeline to meet objectives and overall project } \\
\text { planning. }\end{array}$ \\
\hline Developed rough initial list of clubhouse cost list. & $\begin{array}{l}\text { E) Finish CAD layout of holes \& course to get a } \\
\text { yardage estimation, and 3D model of land \& Pond. }\end{array}$ \\
\hline \multicolumn{2}{|c|}{ Goals for upcoming Week } \\
\hline
\end{tabular}

1. A better understanding what needs to be included in an operating and maintenance business plan for a golf course. (Accomplished by meeting and talking with golf course managers and employees)

2. Need to determine our course needs differentiate it from local golf courses and other university golf courses.

3. Finalize course layout with yardage with yardage estimation and pond location.

4. Obtain more information on costs associated with watering and cutting holes from currently run golf courses. Equipment included.

5. Conceptual sketches and drawings of first scaled clubhouse model.

6. Continue interaction between teams to ensure everyone is on the same page. 